\section{Induced Tolerance to $\mathrm{D}$-Tubocurarine Chloride in the Cat}

IN the course of experimental work we found it necessary to administer a standard dose of $D$-tubocurarine chloride to the same cat on several occasions over a period of months. We observed that in the fifteen animals studied the duration of paralysis of respiratory and other muscle groups became steadily shorter. The work was all done on the intact animal in a warm room. Nitrous oxide in 3:1 mixture with oxygen was the sole anæsthetic agent used-thus, in the preliminary stages no drug was involved which was likely to influence the duration of neuromuscular block. $D$-tubocurarine was administered intravenously in doses of $0.6 \mathrm{mgm}$. $/ \mathrm{kgm}$., and during the period of respiratory paralysis artificial respiration was maintained through an endotracheal tube at a rate of 20-25 per min., a soda lime canister being included in the circuit for the absorption of carbon dioxide. In this way adequate oxygenation was maintained throughout all experiments.

So as to investigate further the apparent change in tolerance to $\mathrm{D}$-tubocurarine we compared the duration of paralysis in the anterior tibialis muscle in a group of six animals which were receiving the drug for the first time with four others which had been rendered tolerant by its repeated administration. The painful stimuli involved in setting up a nervemuscle preparation are such that deeper anæsthesia rather than that provided by nitrous oxide is required. Thiopentone sodium was selected as an extra agent on the grounds that the level of dosage is readily controlled and it is rapidly eliminated from the blood stream. This drug was administered both to experimental and control animals. Anæsthetic induction was therefore carried out with thiopentone sodium, the initial dose of which was 20-50 mgm. Further doses were given as required during the preparatory phase ; but a total of $200 \mathrm{mgm}$. was never exceeded. Endotracheal intubation was performed, and an interval of at least $30 \mathrm{~min}$. allowed to elapse between the last administration of thiopentone sodium and the

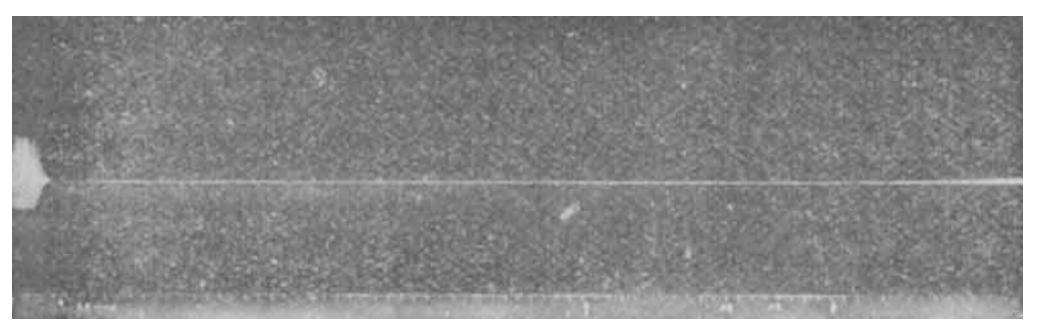

$\uparrow A$ Fig. 1. Myogsaph of a 'normal' cat, No. $18 . A$ indicates intravenous injection of
D-turbocurarine $(0 \cdot 6 \mathrm{mgm} . / \mathrm{kgm}$. body-weight), and $B$ the first perceptable muscie con$\mathrm{mgm} . / \mathrm{kgm}$. body-weight), and $B$ the first per
traction. Time marker, 30 -sec. intervals

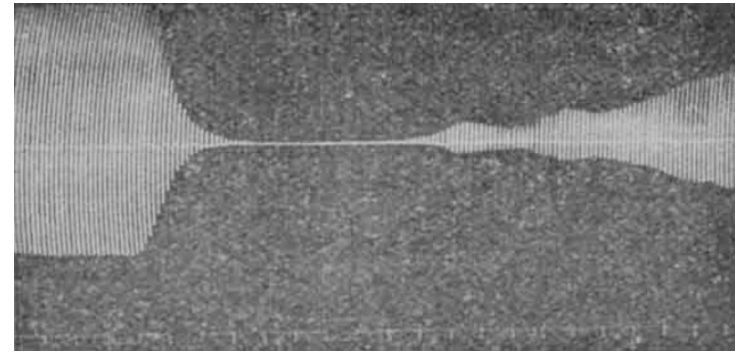

Fig. 2. Myograph of cat No. 14, in which 'tolerance' had been induced. $A$ again indicates the injection of $D$-tubocurarine $(0.6 \mathrm{mgm} . / \mathrm{kgm}$. body-weight); note that muscle contractions never disappear completely

intravenous injection of $\mathrm{D}$-tubocurarine in a dose of $0.6 \mathrm{mgm}$. $/ \mathrm{kgm}$. body-weight. From this time until the end of the experiment, anæsthesia was maintained with a mixture of nitrous oxide and oxygen (3:1).

A Brown-Schuster myograph was used to record the contractions of the anterior tibialis muscle. In order to mimimize temperature drop the limb was mounted horizontally ${ }^{1}$, the skin was sutured over all incisions, and the laboratory was maintained at a temperature of $68^{\circ} \mathrm{F}$. The general environmental conditions were therefore identical to within a few degrees in both groups. Maximal contractions were induced at 4-sec. intervals, through a platinum electrode, and stimulation was continued throughout. The periods elapsing between the administration of D-tubocurarine and the return of muscle contractions, in the four cats in which an altered response to the drug had been induced, are compared with similar periods elapsing in the six cats which had never previously received the drug. The difference between the mean duration of paralysis $(20 \mathrm{~min}$.) in the two groups is significant at the 2 per cent level (Table 1).

Thus we feel that our original observation has been confirmed, and that this is a genuine example of induced drug tolerance. Myograph tracings taken from 'normal' and 'intolerant' animals are shown in Figs. 1 and 2.

The mechanism of this altered response is obscure and is being further examined.

\section{Fiona Acheson* \\ R. J. M. FRY}

Department of Physiology, Trinity College, Dublin.

* Working with a personal grant from the Medical Research Council of Ireland, who also met experimental expenses.

Bigland, B., and Zaimis, E., J. Physiol., 141 420 (1958).

Table 1. Duration of Paralysis of anterior Tibialis Muscle in the Cat duk to D-Tubocurarine Chloride (0.6 Mgm./Kgar. Body-Whight)

\begin{tabular}{|c|c|c|c|c|c|c|c|}
\hline \multicolumn{3}{|c|}{ Animals receiving the drug for the first time } & \multicolumn{5}{|c|}{ Animals rendered tolerant by repeated administration of the drug } \\
\hline $\begin{array}{l}\text { No. of } \\
\text { animal }\end{array}$ & $\begin{array}{l}\text { Body-weight } \\
(\mathrm{kgm} .)\end{array}$ & $\begin{array}{l}\text { Duration of paralysis } \\
\text { (min.) }\end{array}$ & $\begin{array}{l}\text { No. of } \\
\text { animal }\end{array}$ & $\begin{array}{c}\text { Body-weight } \\
\text { (kgm.) }\end{array}$ & $\begin{array}{l}\text { Duration of paralysis } \\
\text { (min.) }\end{array}$ & $\begin{array}{l}\text { No. of previous } \\
\text { injections }\end{array}$ & $\begin{array}{r}\text { Period over which } \\
\text { drug previously give } \\
\text { (weeks) }\end{array}$ \\
\hline $\begin{array}{l}C 18 \\
C 19 \\
C 20 \\
C 21 \\
C 22 \\
C 23 \\
\text { Mean } \\
\text { Variance }\end{array}$ & $\begin{array}{l}3 \cdot 2 \\
2 \cdot 7 \\
2 \cdot 3 \\
2 \cdot 6 \\
2 \cdot 4 \\
1 \cdot 7\end{array}$ & $\begin{array}{c}30 \\
44 \\
31 \\
11 \\
18 \\
25 \\
26 \cdot 5000 \\
108 \cdot 9167\end{array}$ & $\begin{array}{lr}E & 5 \\
E & 12 \\
E & 13 \\
E & 14\end{array}$ & $\begin{array}{l}2 \cdot 7 \\
2 \cdot 3 \\
2 \cdot 7 \\
1 \cdot 5\end{array}$ & $\begin{array}{r}4 \\
11 \\
11 \\
0 \\
\\
6 \cdot 50000 \\
22 \cdot 2500 \\
\end{array}$ & $\begin{array}{r}23 \\
10 \\
9 \\
10\end{array}$ & $\begin{array}{r}74 \\
6 \\
18 \\
13\end{array}$ \\
\hline
\end{tabular}

